\title{
Efektivitas Penerapan Sanksi Administratif Dalam Meningkatkan Kedisiplinan Pemustaka Di Perpustakaan Universitas Negeri Padang
}

\author{
Armiati \\ Fakultas Ekonomi, Universitas Negeri Padang \\ Email: armiati@fe.unp.ac.id \\ Komala Zuha \\ Fakultas Ekonomi, Universitas Negeri Padang \\ Email: komalazuha12@gmail.com
}

\begin{abstract}
Abstrak
Penelitian ini bertujuan menggambarkan kegiatan penerapan sanksi administratif keterlambatan pengembalian bahan pustaka, faktor-faktor penyebab keterlambatan pengembalian bahan pustaka, dampak penerapan sanksi administratif dan juga cara mengatasi keterlambatan pengembalian bahan pustaka di Perpustakaan Universitas Negeri Padang. Metode penelitian ini adalah deskriptif kualitatif, dengan sumber data beberapa informan sesuai kriteria tertentu melalui observasi, hasil wawancara dan dokumentasi. Hasil penelitian menunjukkan bahwa penerapan sanksi administratif telah berjalan dengan baik karena pegawai perpustakaan dan mahasiswa UNP telah bekerja sama dengan baik menjalankan penerapan sanksi administratif sesuai dengan prosedur yang berlaku. Perpustakaan UNP belum melaksanakan kegiatan sosialisasi dengan optimal karena masih banyak mahasiswa yang belum mengetahui keseluruhan tata tertib dan ketentuan sanksi administratif yang berlaku. Perpustakaan UNP hanya menerapkan kegiatan sosialisasi dengan meletakkan banner dan membuat website. Mahasiswa UNP belum merubah perilaku mereka untuk tidak terlambat mengembalikan buku. Masih banyak mahasiswa UNP yang terlambat dalam mengembalikan buku. Faktor penyebab keterlambat pengembalian buku yang dilakukan oleh mahasiswa UNP yaitu 1) lupa tanggal jatuh tempo pengembalian buku, 2) buku masih diperlukan, 3) pulang kampung 4) jadwal kuliah yang padat, 5) meminjamkan KTM ke teman dan teman lupa mengembalikan buku tersebut, 6) buku dipinjam teman dan 7) banyak tugas. Adanya sanksi administratif belum menimbulkan efek jera kepada mahasiswa UNP. Cara mengatasi keterlambatan pengembalian buku perlu kerjasama antar perpustakaan UNP dengan mahasiswa UNP.
\end{abstract}

Kata Kunci: Efektivitas, Sanksi Administratif, Kedisiplinan.

\begin{abstract}
This study aims to describe the activities of administrative sanctions implementation of the delay in returning library materials, factors that cause delays in returning library materials, the impact of implementing administrative sanctions and also how to overcome delays in returning library materials at Library of Padang State University. This research method is descriptive qualitative, with data sources some informants fit certain criteria through observation, interviews and documentation. Based on the information from the informants of this study, it can be explained that the application of administrative sanctions has gone well because Library employees and UNP students have cooperated well in implementing administrative sanctions in accordance with the applicable procedures. The Library of UNP has not carried out the socialization activities optimally because there are still many students who do not know the entire rules and the provisions of the administrative sanctions that apply. The library of UNP only applies socialization activities by placing banners and creating websites. Students of UNP have not changed their behavior to not late returning books. There are still many UNP students who are late in returning books. Factors that cause delays in returning books made by UNP students are 1) forgetting the return date of the book, 2) books still needed, 3) returning home 4) busy lecture schedule, 5) lending KTM to friends and friends forgetting to return the book, 6) books borrowed by friends and 7) many tasks. The existence ofadministrative sanctions has not caused a deterrent effect on UNP
\end{abstract}


students. How to overcome delays in returning books needs collaboration between UNP's Library and UNP's students.

Keywords:Effectiveness, Administrative Sanctions, Discipline.

\section{PENDAHULUAN}

Keberadaan perpustakaan ditengah masyarakat membantu masyarakat dalam mendapatkan sumber informasi yang beragam. Hal ini sebagaimana telah dijelaskan oleh Suwarno (2009: 40) "bahwa perpustakaan yang baik bisa dilihat dari kinerjanya, artinya perpustakaan itu baik dalam pengelolaannya dan menjalankan kegiatan perpustakaan sesuai dengan visi dan misinya, sehingga dapat menjadi pusat informasi yang positif bagi masyarakat”. Salah satu perpustakaan yang berada di lingkungan Universitas Negeri Padang adalah perpustakaan pusat Universitas Negeri Padang yang merupakanbagian dari unit kerja yang mempunyai tugas pokok memberikan layananinformasi literatur kepada pemustaka untuk membantu kelancaranproses pembelajaran.

Keberadaan perpustakaan pada institusi pendidikan sangat penting bagikemajuan dan perkembangan institusi, sebab perpustakaan merupakansalah satu penyedia informasi yang sering dibutuhkan pendidikan dan penelitian (Pratama, 2014). Selama proses pembelajaran, salah satu pemustaka yang rutin memanfaatkan seluruh fasilitas perpustakaan UNP yakni mahasiswa yang berhak menikmati pelayanan dan sumber informasi untuk perkuliahan dan penelitian. Sumber informasi yang dibutuhkan oleh mahasiswa sangat beragam sehingga perpustakaan UNP harus dapat memenuhi segala kebutuhan mahasiswa demi kelancaran studi mereka. Jika telah terpenuhinya segala kebutuhan pemustaka maka dapat dikatakan perpustakaan tersebut memiliki manajemen yang baik dalam pengelolaannya. Terdapat kegiatan-kegiatan perpustakaan yang harus dijalankan dengan baik agar terciptanya keteraturan dalam bertingkah laku dan pemanfaatan bahan pustaka tentunya.

Terdapat kasus pelanggaran peraturan dilingkungan perpustakaan yaitu mengenai keterlambatan pengembalian bahan pustaka yang sering terjadi. Kebanyakan pemustaka mengakui sering terlambat dalam mengembalikan bahan pustaka Suriptiani (2016). Hasil penelitian ini menunjukkan 54\% atau sebanyak 54 responden setuju sering melanggar peraturan dalam bentuk keterlambatan dalam mengembalikan bahan pustaka di perpustakaan. Selain itu, pelanggaran keterlambatan pengembalian bahan pustaka lain juga dilakukan oleh pemustaka di kantor Perpustakaan dan Arsip Kabupaten Banyumas yang tergolong tinggi Wismanawati (2013) 
Disiplin sangat penting untuk diterapkan di lingkungan perpustakaan. Menurut Hasibuan (2005: 193), "kedisiplinan yakni kesadaran dan kesediaan seseorang menaati semua peraturan perusahaan dan norma-norma sosial yang berlaku”. Jadi, disiplin adalah kesadaran seseorang untuk mengikuti peraturan yang ada sehingga tercipta norma yang sesuai dengan aturan yang berlaku dimasyarakat. Tingkat kedisiplinan para pemustaka khususnya mahasiswa Universitas Negeri Padang dapat kita lihat pada data jumlah mahasiswa yang terlambat mengembalikan bahan pustaka dan pemberian sanksi oleh pihak perpustakaan UNP berupa denda. Jumlah mahasiswa yang terlambat mengembalikan bahan pustaka dapat kita lihat pada tabel 1 .

Tabel 1. Data pemustaka yang terlambat mengembalikan bahan pustaka dan jumlah sirkulasi buku yang dikenakan denda selama tahun 2015 s/d 2017

\begin{tabular}{|c|c|c|c|}
\hline No. & Tahun & Jumlah Eksemplar Denda & Jumlah Pemustaka \\
\hline 1. & 2015 & 40.371 & 376 \\
\hline 2. & 2016 & 34.531 & 443 \\
\hline 3. & 2017 & 33.865 & 535 \\
\hline
\end{tabular}

Sumber: Perpustakaan UNP, 2018

Dari tabel 1 dapat kita lihat bahwa dari tahun 2015-2017 masih banyak mahasiswa dan pemustaka lainnya yang terlambat mengembalikan bahan pustaka sehingga berdampak pada denda yang harus dibayarkan. Serta dapat kita lihat bahwa jumlah sirkulasi buku yang dikenakan denda dari tahun 2015-2017 juga tergolong banyak. Walaupun data dari tabel 1 menunjukkan bahwa jumlah mahasiswa yang terlambat mengembalikan buku cenderung menurun, tapi tetap saja jumlah angkanya masih tergolong besar. Hal ini menunjukkan bahwa pemustaka khususnya mahasiswa belum menanamkan sikap disiplin didalam diri mereka sehingga banyak keterlambatan pengembalian buku yang terjadi. Keterlambatan pengembalian buku oleh mahasiswa UNP disebabkan oleh berbagai alasan seperti lokasi perpustakaan jauh, pulang kampung, lupa kalau telah meminjam buku di Perpustakaan, buku masih diperlukan, malas pergi ke perpustakaan, jadwal kuliah padat, dan juga ada yang berpendapat kalau dendanya tidak terlalu besar. Bahkan denda terbesar yang pernah didapatkan oleh Perpustakaan UNP yaitu sebesar Rp. 1.000.000.

Penegakan hukum disiplin sangat penting dalam rangka untuk mewujudkan perpustakaan yangmemenuhi standar nasional pengelolaan sebuah perpustakaan yang ada (Supriyadi, 2015). Disiplin ditujukan agar sebuah perpustakaan dapat terkelola dengan baik. Kedisiplinan sangat perlu diterapkan di Perpustakaan UNP agar mahasiswa dapat mematuhi tata tertib dan peraturan yang berlaku di Perpustakaan UNP. Tata tertib dan peraturan yang diterapkan hendaknya berjalan secara efektif. Tetapi selama observasi masih banyak 
mahasiswa UNP yang tidak mematuhi tata tertib dan peraturan yang ada, hal ini dibuktikan dengan masih banyaknya mahasiswa yang terlambat mengembalikan buku dan ada juga mahasiswa yang kurang mengetahui keseluruhan tata tertib dan peraturan yang berlaku.

Maka dari pada itu, untuk meningkatkan kedisiplinan pemustaka dalam menjalankan tata tertib perpustakaan, perlunya penerapan sanksi administratif yang efektif. Dengan adanya penerapan sanksi administratif yang dilakukan diharapkan pemustaka lebih disiplin dalam mengembalikan bahan pustaka dan dapat menerapkan secara maksimal tata tertib yang berlaku.

Sanksi yang mengatur kegiatan administrasi di perpustakaan UNP yaitu sanksi administratif. Menurut Van dalam Anggraini (2012: 185) "sanksi administrative adalah sanksi yang merupakan sarana-sarana kekuatan menurut hukum publik yang dapat diterapkan oleh badan atau pejabat TUN (Tata Usaha Negara) sebagai reaksi dari terhadap mereka yang tidak mentaati norma-norma hukum. Jadi, sanksi administratif merupakan sanksi yang diterapkan oleh pihak tata usaha agar dapat mentaati ketentuan-ketentuan yang berlaku dalam bidang administrasi. Sanksi administratif diterapkan sebagai bahan kebijakan yang dirumuskan berdasarkan kepentingan bersama antara pihak perpustakaan sebagai pembuat kebijakan dan pengunjung perpustakaan yang memanfaatkan layanan perpustakaan. Perpustakaan menerapkan sanksi administratif agar seluruh bahan pustaka dapat terjaga dengan baik dan dapat digunakan dalam jangka waktu yang lama. Adanya sanksi administratif diharapkan dapat menciptakan kedisiplinandalam memanfaatkan fasilitas bagi pemustaka.

Penerapan sanksi administratif diharapkan agar pemustaka selalu mentaati dan mematuhi kebijakan yang ditetapkan perpustakaan. Pemberian sebuah sanksi administrasi seperti denda merupakan salah satu cara untuk mengelola perpustakaan dengan baik. Dengan adanya kepastian sanksi administrasi tersebut diharapkan semua pihak dapat mematuhi aturan yang berlaku Supriyadi (2015). Ketaatan dan kepatuhan akan kebijakan perpustakaan merupakan salah satu hal yang akan melahirkan kebiasaan disiplin didalam diri pemustaka. Kesadaran akan disiplin dapat timbul karena adanya sanksi administratif yang ada. Dengan adanya sanksi administratif tersebut maka pemustaka takut untuk melakukan pelanggaran. Oleh karena itu, kedisiplinan dapat dilatih didalam diri mahasiswa sehingga peraturan yang ada dapat dipatuhi dan meminimalisir terjadinya pelanggaran. Pada kenyataannya masih terjadi pelanggaran di Perpustakaan UNP karena tidak adanya ketakutan akan sanksi administratif yang telah ditetapkan. 
Ketidakdisiplinan pemustaka akan berdampak pada pengelolaan bahan pustaka yang ada seperti buku yang tidak dikembalikan sesuai dengan jangka waktu yang telah ditetapkan. Sehingga sangat diperlukan peraturan dan sanksi administratif yang kuat agar dapat menjamin kelancaran manajemen perpustakaan tersebut. Sanksi administratif yang diterapkan harus berupa sanksi administatif yang membuat pemustaka dapat mengembalikan bahan pustaka tepat waktu. Penerapan sanksi administratif tersebut hendaknya dapat diketahui oleh pemustaka yang berkunjung ke perpustakaan. Terkadang pemustaka hanya berkunjung sekali selama jangka waktu yang lama sehingga pemustaka tidak mengetahui sanksi administratif seperti apa yang diterapkan oleh perpustakaan tersebut. Sehingga perlu adanya sosialisasi oleh pihak perpustakaan terhadap sanksi administratif yang diterapkan agar tidak terjadi kekeliruan bagi pemustaka.Tujuan penelitian ini adalah untuk menggambarkan efektivitas penerapan sanksi administratif dalam meningkatkan kedisiplinan pemustaka di Perpustakaan Universitas Negeri Padang.

\section{METODE}

Metode penelitian ini berupa deskriptif kualitatif. Penelitian ini dilaksanakan di Perpustakaan Universitas Negeri Padang dan lingkungan Universitas Negeri Padang. Teknik pengambilan sampel yang digunakan adalah purposive sampling. Teknik pengumpulan data yang dilakukan adalah observasi, wawancara dan dokumentasi. Instrumen penelitian yang digunakan adalah pedoman wawancara dan alat perekam. Sumber data dari penelitian ini adalah data primer yang diperoleh dari objek penelitian yang dikumpulkan peneliti dari informan melalui hasil wawancara dan pengamatan langsung kepada subjek penelitian sedangkan data sekunder merupakan data pendukung penelitian yang diperoleh dari dokumendokumen. Untuk menguji keabsahan data digunakan triangulasi teknik. Data yang diperoleh melalui sumber yang sama dari berbagai teknik yang dilakukan yaitu observasi, wawancara dan dokumentasi sehingga menghasilkan data yang lebih teruji kebenarannya.

\section{HASIL DAN PEMBAHASAN}

\section{Efektivitas Penerapan Sanksi Administratif}

Sanksi administratif merupakan sanksi yang diterapkan oleh perpustakaan Universitas Negeri Padang yang bertujuan agar pemustaka dapat mematuhi segala peraturan yang berlaku di perpustakaan UNP. Sanksi ini juga berguna untuk menghukum siapa saja yang melanggar peraturan yang ada. Hal ini sebagaimana yang disampaikan oleh Van dalam Anggraini (2012: 185) sanksi administratif adalah sanksi administratif itu merupakan sarana-sarana kekuatan 
menurut hukum publik yang dapat diterapkan oleh badan atau pejabat TUN (Tata Usaha Negara) sebagai reaksi dari terhadap mereka yang tidak mentaati norma-norma hukum TUN (Tata Usaha Negara)". Hal ini sama halnya dengan yang diungkapkan oleh Rahayuningsih (2007: 98) bahwa sanksi administrasi, sanksi berupa hukuman secara administrasi yang diberikan kepada pemustaka. Misalnya tidak boleh meminjam koleksi dalam kurun waktu tertentu, atau dikeluarkan dari keanggotaan perpustakaan.

Efektivitas penerapan sanksi administratif diukur dari tiga pembahasan yang terdiri dari pencapaian tujuan, integrasi dan adaptasi. Pertama yaitu mengenai pencapaian tujuan mengenai penerapan sanksi administratif dalam hal keterlambatan pengembalian bahan pustaka. Penerapan sanksi administratif dalam hal keterlambatan pengembalian buku dikatakan efektif jika penerapan tata tertib pengembalian buku telah berjalan sesuai prosedur dan juga telah dipatuhi dengan baik oleh pemustaka. Jadi pencapaian tujuan dalam hal penerapan sanksi dapat berjalan sesuai dengan prosedur yang telah ditetapkan. Selama melakukan penelitian, penerapan sanksi administratif keterlambatan pengembalian buku di perpustakaan UNP sudah berjalan sesuai dengan perencanaan pihak perpustakaan UNP sehingga tujuan penerapan sanksi telah tercapai karena mulai dari pemustaka dan petugas perpustakaan UNPsudah menjalankan tata tertib dan ketentuan sanksi dalam hal pengembalian buku ini. Selain itu, penerapan sanksi administratif dilaksanakan dengan menggunakan sistem pencatatan denda yang memudahkan petugas untuk mengetahui buku yang sudah terkena denda melalui sistem tersebut. Setelah pemustaka yang terlambat mengembalikan buku telah dicatat dalam sistem pencatatan denda, maka pemustaka tersebut diberikan sebuah slip pembayaran denda digunakan sebagai bukti bahwa pemustaka terlambat mengembalikan buku dan juga sebagai pertanggung jawaban pihak Perpustakaan UNP sebagai pendapatan.

Penerapan sanksi administratif keterlambatan pengembalian bahan pustaka dilaksanakan dengan menggunakan beberapa prosedur yang harus dijalankan oleh pihak perpustakaan dan juga pemustaka khususnya mahasiswa, prosedur tersebut yaitu 1) pengguna menyerahkan buku dan KTM ke petugas, 2) petugas menscan KTM buku, 3) jika terlambat petugas memprint kwitansi denda, pemustaka membayar denda, dan kwitansi diserahkan ke pemustaka dan satu lagi untuk petugas, 4) jika tepat waktu maka hanya scan KTM dan buku setelah itu selesai, 5) dan otomatis buku berhasil dikembalikan dan dihapus dari sistem peminjaman. Prosedur pengembalian koleksi bahan pustaka pada kenyataannya telah berjalan sesuai dengan prosedur yang ada. Selain itu, mahasiswa juga merasakan secara langsung prosedur tersebut serta petugas dan mahasiswa melaksanakan prosedur tersebut dengan baik. 
Jadi, poin-poin diatas secara keseluruhan telah dijalankan dengan baik oleh mahasiswa maupun petugas perpustakaan UNP.

Pencapaian tujuan dalam hal efektivitas penerapan sanksi administratif yang terdapat di perpustakaan UNP sudah berjalan dengan baik. perpustakaan UNP telah menjalankan tata tertib sebaik mungkin sehingga tercapai tujuan agar seluruh kegiatan dalam memanfaatkan fasilitas perpustakaan dapat berjalan dengan tertib sesuai prosedur yang ada. Sama halnya dengan pendapat yang diungkapkan oleh Rahayu (2014: 1.32) "untuk menunjang kelancaran dan keteraturan pelaksanaan kegiatan layanan perpustakaan perlu diterapkan peraturan dan tata tertib yang wajib dipatuhi oleh seluruh pemustaka dan dijadikan pegangan bagi petugas bagian pelayanan". berdasarkan informasi yang didapatkan peneliti dari informan, maka dapat disimpulkan bahwa perpustakaan UNP dan Mahasiswa UNP telah menjalankan tata tertib dan sanksi dalam hal keterlambatan pengembalian buku yang ditetapkan dengan sebaik mungkin. Sehingga dengan kerjasama yang baik antara perpustakaan UNP dan mahasiswa UNP maka penerapan sanksi administratif dapat berjalan dengan optimal.

Penerapan sanksi administratif keterlambatan pengembalian bahan pustaka juga diukur dengan menggunakan poin mengenai integrasi yaitu pengukuran terhadap tingkat kemampuan suatu organisasi untuk mengadakan sosialisasi, pengembangan konsensus dan komunikasi dengan organisasi lainnya. Integrasi dapat dilihat dari prosedur yang ditetapkan dan proses sosialisasi itu sendiri sehingga terciptalah komunikasi yang baik diantara anggota organisasi. Penerapan sanksi administratif dilaksanakan dengan cara memberikan sosialisasi agar semua pihak mengetahui sanksi administratif serta tentunya tata tertib yang diterapkan oleh perpustakaan UNP. Perpustakaan UNP melaksanakan kegiatan sosialisasi dalam bentuk membuat banner dan juga website. Tetapi kegiatan sosialisasi yang diterapkan di perpustakaan UNP belum efektif karena masih banyak mahasiswa yang kurang mengetahui secara jelas mengenai tata tertib dan ketentuan sanksi yang berlaku.

Jadi dari beberapa pernyataan diatas dapat disimpulkan bahwa kegiatan sosialisasi sudah dilakukan oleh pihak Perpustakaan UNP dengan cara meletakkan banner-banner yang berisikan tata tertib dan alur-alur peminjaman, pengembaliakn, dan juga pemanfaatan Perpustakaan UNP secara keseluruhan untuk memberitaukan pemustaka mengenai tata tertib. Banner-banner tersebut bertujuan agar mahasiswa dapat membaca banner-banner tersebut dan dapat menjalankan setiap prosedur yang dicantumkan disana. Banner-banner tersebut sangat membantu bagi pemustaka agar dapat memanfaatkan fasilitas Perpustakaan UNP dengan sebaik mungkin dan tentunya bertanggung jawab. 
Selain banner, Perpustakaan UNP juga menerapkan sosialisasi mengenai tata tertib dan ketentuan sanksi dengan cara membuat website. Tetapi berdasarkan hasil wawancara peneliti dengan beberapa mahasiswa UNP, mereka rata-rata tidak mengetahui adanya website tersebut.

Beberapa informan memberitaukan bahwa sosialisasi juga dilakukan secara langsung jika pemustaka bertanya kepada pustakawan dan pustakawan memberitaukannya. Dari hasil wawancara juga diketahui bahwasanya beberapa tahun lalu kegiatan sosialisasi khusus pernah dilakukan oleh pihak perpustakaan UNP pada saat PKKMB bagi mahasiswa baru. Tetapi saat ini tidak ada kegiatan seperti itu. Sehingga selama wawancara kepada mahasiswa, mahasiswa tidak merasakan adanya kegiatan sosialisasi dari pihak Perpustakaan UNP sehingga beberapa mahasiswa tidak mengetahui secara jelas mengenai beberapa tata tertib dan ketentuan sanksi yang berlaku. Mereka mengetahui tata tertib dan ketentuan sanksi dari teman-teman dan juga memperhatikan orang lain. Dapat disimpulkan bahwa kegiatan sosialisasi yang diterapkan di Perpustakaan UNP belum efektif karena masih banyak mahasiswa yang kurang mengetahui secara jelas mengenai tata tertib dan ketentuan sanksi yang berlaku.

Sosialisasi sangat diperlukan agar perpustakaan menjadi lebih baik dan dipandang positif oleh pemustaka. Hal ini sebagaimana dijelaskan oleh Sutarno (2006: 212) "sosialisasi perpustakaan adalah dalam rangka membangun citra, atau image yang positif'. Jadi dengan adanya sosialisasi dapat membangun image positif dan kedepannya Perpustakaan UNP lebih baik lagi. Sosialisasi diperlukan guna mempertahankan dan menjaga kelangsungan promosi atau bisa dengan diadakannya kegiatan yang melibatkan masyarakat. Sosialisasi dapat dilakukan dengan berbagai cara seperti yang diungkapkan oleh Sutarno (2006: 213-214) mengungkapkan bentuk sosialisasi dapat dilakukan dengan berbagai cara, misalnya melalui banyak cara antara lain: media cetak seperti penyebaran brosur, pembuatan daftar tambahan koleksi baru, pemajangan koleksi baru di papan pengumuman agar menarik pemustaka datang ke perpustakaan, melalui media elektronik misalnya membuat home page dan website, dan membuat pangkalan data yang dapat diakses, membuat iklan layanan sosial, membuat film dokumenter, mengundang pejabat dan tokoh publik, seperti pengarang buku, mengadakan berbagai kegiatan yang melibatkan keikutsertaan masyarakat, misalnya perlombaan pameran, lomba menulis dan lain-lain, mengadakan seminar ilmiah, diskusi, bedah buku dan lain sebagainya, memberikan hadiah buku kepada pemustaka

Sosialisasi yang telah dijalankan oleh perpustakaan UNP yaitu hanya dengan membuat banner-banner yang berisikan tulisan mengenai tata tertib serta alur pemanfaatan perpustakaan. Dan juga bentuk sosialisasinya berupa website tetapi mahasiswa secara 
keseluruhan tidak pernah tau dan tidak pernah membuka website tersebut. Perpustakaan UNP sampai tahun 2012 telah menjalankan kegiatan sosialisasi pada saat mahasiswa baru menjalankan kegiatan PKKMB, tetapi dari tahun 2013 sampai sekarang perpustakaan UNP tidak lagi mengisi kegiatan sosialisasi selama kegiatan PKKMB. Sebenarnya sudah bagus Perpustakaan UNP melakukan sosialisasi seperti membuat banner dan juga website, tetapi alangkah lebih baiknya Perpustakaan UNP bisa melakukan lebih banyak lagi kegiatan sosialisasi seperti mengundang pengarang buku untuk bedah buku, mengadakan kegiatan yang melibatkan mahasiswa dan civitas akademis UNP seperti kegiatan PKKMB dan bisa juga memberikan hadiah buku kepada mahasiswa.

Penerapan sanksi administratif yang terakhir diukur melalui poin adaptasi. Adaptasi adalah sebuah proses penyesuaian diri seorang individu untuk menyelaraskan dengan perubahan-perubahan yang akan dan telah terjadi dilingkungannya. Efektivitas penerapan sanksi administratif juga dapat dilihat peningkatan kemampuan pemustaka untuk tepat waktu dalam mengembalikan bahan pustaka. Sehingga terjadi peningkatan kedisiplinan dari pemustaka tersebut dalam mengembalikan bahan pustaka. Hasil penerapan sanksi administratif dapat dilihat dari peningkatan kedisiplinan mahasiswa dalam mematuhi tata tertib yang berlaku. Khususnya kedisiplinan mahasiswa dalam ketepatan waktu pengembalikan bahan pustaka di perpustakaan UNP. Dari pengamatan penulis, mahasiswa UNP masih banyak yang terlambat dalam mengembalikan buku, dan mereka harus membayar denda keterlambatan tersebut.

Selain itu, selama penelitian, peneliti juga menemukan beberapa mahasiswa yang hanya sekali terlambat dalam mengembalikan buku dan ada yang membayar denda dalam jumlah yang besar dan jumlah yang kecil. Penerapan sanksi administratif ditujukan agar mahasiswa tidak terlambat dalam mengembalikan buku sehingga mahasiswa lain bisa menggunakan buku tersebut secara bergiliran. Sanksi yang ditetapkan oleh pihak perpustakaan UNP jika terlambat mengembalikan buku yaitu sanksi berupa denda dan juga sanksi mengenai pemblokiran portal jika sudah 1 semester tidak mengembalikan buku. Sanksi tersebut hendaknya dapat menimbulkan perubahan tingkah laku mahasiswa agar tepat waktu dalam mengembalikan buku. Jadi, dapat disimpulkan sesuai dengan wawancara selama penelitian dan pengamatan peneliti, sanksi yang ditetapkan tersebut tidak membuat mahasiswa jera untuk terlambat mengembalikan buku sehingga jumlah keterlambatan pengembalian buku tergolong besar. Selanjutnya, sanksi berupa denda sebesar Rp. 1000 sudah cukup baik diterapkan di perpustakaan UNP. Tetapi dengan sanksi berupa uang tersebut sepertinya belum memberikan perubahan tingkah laku agar mahasiswa tidak 
terlambat lagi dalam mengembalikan buku. Kebanyakan mahasiswa tidak terlalu mempedulikan denda tersebut dan memilih untuk terlambat mengembalikan buku karena alasan-alasan yang dibuat oleh mahasiswa.

Efektivitas penerapan sanksi administratif dapat dilihat dari peningkatan kemampuan dalam hal kedisiplinan untuk tepat waktu dalam mengembalikan buku oleh mahasiswa. Menurut Sinungan (2008: 145) disiplin adalah "suatu sikap yang menggambarkan perbuatan masyakat yang patuh terhadap peraturan-peraturan yang telah diatur oleh pihak terkait untuk mencapai tujuan tertentu sehingga dapat mematuhi norma sosial yang berlaku". Secara keseluruhan berdasarkan wawancara peneliti dengan mahasiswa, mahasiswa masih banyak terlambat dalam mengembalikan buku bahkan ada yang sudah berkali-kali terlambat dalam mengembalikan buku. Tetapi ada juga yang hanya sekali terlambat dalam mengembalikan buku. Jumlah uang yang dibayarkan oleh mahasiswa tidak begitu besar. Rata-rata hanya dibawah Rp. 10.000 dan hanya beberapa mahasiswa yang membayar denda diatas Rp. 10.000. Peneliti juga melakukan pengamatan dibagian pengembalian buku, dan peneliti mengamati bahwa setiap beberapa waktu peneliti melihat barisan mahasiswa yang terlambat dalam mengembalikan buku. Hal ini menandakan bahwa mahasiswa UNP belum mematuhi tata tertib dalam mengembalikan UNP dan dapat dilihat bahwa kedisiplinan mahasiswa UNP masih rendah karena masih banyaknya keterlambatan pengembalian buku yang terjadi.

\section{Faktor Penyebabkan Keterlambatan Dalam Hal Pengembalian Bahan Pustaka}

Faktor penyebab keterlambatan mahasiswa dalam mengembalikan buku merupakan alasan bagi mahasiswa untuk melakukan keterlambatan tersebut. Faktor penyebab keterlambatan pengembalian buku oleh mahasiswa karena lupa tanggal jatuh tempo pengembalian buku, buku masih diperlukan, pulang kampung, jadwal kuliah yang padat, meminjamkan KTM ke teman dan teman lupa mengembalikan buku tersebut, buku dipinjam teman dan banyak tugas. Faktor-faktor seperti itu diungkapkan oleh seluruh informan peneliti, baik itu mahasiswa maupun pihak perpustakaan UNP sendiri. Keterlambatan pengembalian buku tidak akan terjadi jika faktor-faktor tersebut bisa diminimalisasi ataupun dihindari. Mahasiswa sebenarnya bisa mencari jalan keluar agar keterlambatan tidak terjadi lagi sehingga tidak akan merugikan mereka tentunya.

Faktor penyebab keterlambatan pengembalian buku yaitu yang pertama karena mahasiswa lupa tanggal jatuh tempo pengembalian buku. Rata-rata informan yang peneliti jumpai menyatakan bahwa mereka lupa tanggal tersebut sehingga tidak mengembalikannya tepat waktu dan mereka terlambat. Faktor penyebab yang lain yaitu karena mahasiswa 
tersebut meminjamkan KTM mereka ke teman untuk meminjam buku dan teman tersebut ada yang lupa mengembalikan buku tersebut dan berakibat terkena denda. Berdasarkan wawancara peneliti dengan petugas denda, denda terbesar yang pernah diterima oleh perpustakaan UNP yaitu sebesar Rp. 1.000.000 dan alasan mahasiswa tersebut sama, mahasiswa tersebut meminjamkan KTM ke temannya dan temannya tersebut lupa mengembalikan buku di perpustakaan dalam jangka waktu yang lama. Kejadian seperti ini sangat merugikan mahasiswa sendiri karena harus mengeluarkan uang dalam jumlah yang banyak. Mahasiswa UNP terlambat mengembalikan buku juga dikarenakan buku tersebut masih diperlukan untuk membuat tugas dan dalam menunjang perkuliahan sehingga waktu seminggu tidak cukup untuk meminjam buku. Penyebab keterlambatan lainnya yaitu karena jadwal kuliah yang padat, banyak tugas dan tidak sempat untuk ke perpustakaan UNP. Hal ini diungkapkan oleh Hidayat (2014) bahwa faktor keterlambatan pengembalian buku dikarenakan buku dipinjam teman, buku tersebut belum selesai dibaca dan tidak ada waktu pergi ke perpustakaan.

\section{Dampak Penerapan Sanksi Administratif Dalam Meningkatkan Kedisiplinan Pemustaka}

Dampak penerapan sanksi administratif diharapkan dapat mengubah perilaku mahasiswa agar tepat waktu dalam mengembalikan buku. Hasil dari penelitian mengenai dampak penerapan sanksi admnistratif ini yaitu dengan adanya sanksi keterlambatan yang ditetapkan saat ini mahasiswa masih banyak yang terlambat mengembalikan buku. Bahkan masih ada mahasiswa yang terlambat lebih dari sekali selama meminjam buku di perpustakaan UNP. Berdasarkan pengamatan peneliti dengan adanya sanksi keterlambatan buku masih banyak mahasiswa yang terlambat mengembalikan buku. Jadi, dapat disimpulkan bahwa dampak penerapan sanksi administratif di perpustakaan UNP belum membuat mahasiswa disiplin dalam mengembalikan buku. Selama peneliti melakukan wawancara dengan pihak perpustakaan UNP, mereka menyatakan bahwa sanksi yang diterapkan saat ini belum memberikan dampak berupa efek jera kepada mahasiswa sehingga mahasiswa masih banyak yang terlambat dalam mengembalikan buku. Hal ini bisa dinyatakan bahwa dengan adanya sanksi administratif yang diterapkan pihak perpustakaan UNP belum bisa meningkatkan kedisiplinan mahasiswa dalam mengembalikan buku.

Mahasiswa UNP masih banyak yang terlambat mengembalikan buku bahkan ada yang lebih dari sekali terlambat mengembalikan buku. Hal ini menandakan bahwa mahasiswa UNP belum mematuhi tata tertib pengembalian buku. Adanya sanksi yang tegas pada seseorang 
yang melanggar disisplin dengan tujuan untuk memberikan efek jera dan shock terapi agar pemustaka lain tidak melakukan pelanggaran lagi Supriyadi (2015). Dampak penerapan sanksi administratif selanjutnya yaitu agar memberikan efek jera kepada mahasiswa. Dengan adanya sanksi berupa denda diharapkan mahasiswa jera dan tidak terlambat lagi dalam mengembalikan buku. Tetapi dengan denda Rp. 1000 yang ditetapkan oleh pihak perpustakaan UNP mahasiswa masih saja terlambat mengembalikan buku. Berdasarkan wawancara dengan informan penelitian, mahasiswa UNP tidak merasakan jera untuk tidak terlambat lagi dalam mengembalikan buku dengan denda Rp. 1000 tersebut. Dan juga karena alasan-alasan terlambat mengembalikan buku maka mahasiswa selalu terlambat dalam mengembalikan buku. Sanksi administratif diterapkan agar mahasiswa UNP tidak lagi terlambat dalam mengembalikan buku. Dengan adanya sanksi administratif, maka mahasiswa UNP agar lebih bertanggung jawab dan sadar bahwa buku yang tersedia tidaklah sebanyak mahasiswa maka buku tersebut dipakai secara bergiliran maka dari itu sebaiknya mahasiswa tepat waktu mengembalikan buku.

\section{Cara Mengatasi Permasalahan Keterlambatan Pengembalian Bahan Pustaka}

Pihak perpustakaan UNP sudah menerapkan jalan keluar untuk mengatasi keterlambatan pengembalian buku. Peneliti telah mewawancarai pihak perpustakaan UNP untuk mengetahui cara apa saja yang telah dilakukan mereka untuk mengatasi keterlambatan pengembalian buku. Cara pihak perpustakaan untuk mengatasi keterlambatan yaitu memberikan stempel tanggal pengembalian pada belakang bagian buku dan juga menerapkan sanksi berupa denda dan pemblokiran portal. Mahasiswa tentunya juga harus menemukan cara agar tidak terlambat lagi dalam mengembalikan buku dengan cara mengingat tanggal pengembalian buku, memfotocopy buku dan dengan cara mengembalikan buku sebelum tanggal jatuh tempo pengembalian buku. untuk mengatasi keterlambatan pengembalian buku perlunya kerjasama antara pihak perpustakaan UNP dengan pemustaka khususnya mahasiswa UNP agar tata tertib pengembalian buku dapat dijalankan dengan baik dan jumlah keterlambatan pengembalian buku dapat berkurang seiring berjalannya waktu.

Cara yang tepat untuk mengatasi keterlambatan pengembalian bahan pustaka yaitu harus adanya sikap untuk meningkatkan kedisiplinan dari mahasiswa dan juga usaha perpustakaan UNP untuk menjadikan mahasiswa disiplin dalam mengembalikan bahan pustaka. Sebagian besar perpustakaan menerapkan sanksi berupa denda jika pemustaka terlambat dalam mengembalikan bahan pustaka yang dipinjam Maryatun (2016).Perpustakaan UNP juga menerapkan sanksi berupa denda bagi mahasiswa yang terlambat mengembalikan buku. 
Keterlambatan pengembalian buku bisa diatasi dengan melakukan kerjasama antar pihak perpustakaan UNP dengan mahasiswa UNP. Perpustakaan UNP sudah melakukan kegiatan agar mahasiswa UNP tidak terlambat lagi dalam mengembalikan buku. Cara mereka yaitu dengan memberikan stempel pengembalian buku. Hal lain juga dilakukan oleh pihak Perpustakaan UNP yaitu dengan melakukan pemblokiran portal jika mahasiswa belum mengembalikan buku selama 6 bulan. Pada saat mengakses portal maka mahasiswa yang belum mengembalikan buku tersebut tidak bisa mengakses portal untuk mengambil mata kuliah pada pergantian semester. Berdasarkan wawancara yang dilakukan penelti kepada mahasiswa bahwa mereka juga melakukan usaha agar tidak terlambat lagi dalam mengembalikan buku. Cara mereka yaitu dengan mengingat tanggal jatuh tempo pengembalian buku, memfotocopy halaman yang diperlukan dan juga mengembalikan buku sebelum jatuh tempo. Cara ini sangat bagus bagi mahasiswa agar lebih sadar untuk tepat waktu dalam mengembalikan buku. Beberapa informan penelitian juga setuju jika perpustakaan UNP menerapkan sanksi lain seperti sistem skorsing dan juga sanksi sosial.

\section{PENUTUP}

\section{Simpulan}

Efektivitas penerapan sanksi administratif dalam meningkatkan kedisiplinan pemustaka di Perpustakaan Universitas Negeri Padang sudah cukup berjalan dengan baik. Hal ini dapat dilihat dari jalannya penerapan sanksi administratif sudah dilaksanakan dengan optimal antara pihak perpustakaan UNP dengan mahasiswa UNP tentunya. Sanksi administratif yang diterapkan di perpustakaan UNP sudah dikenakan bagi mahasiswa UNP yang terlambat mengembalikan buku. mahasiswa UNP sudah merasakan secara langsung proses penerapan sanksi administratif tersebut karena mereka membayar denda yang dikenakan dan mereka mendapatkan slip pembayaran sebagai bukti pembayaran denda yang diberikan oleh petugas disana. Kegiatan sosialisasi juga terdapat di perpustakaan UNP dalam bentuk banner dan tulisan yang diletakkan di seluruh lingkungan perpustakaan UNP. Sanksi administratif diterapkan belum membuat perubahan kepada tingkah laku mahasiswa agar lebih disiplin karena masih banyak yang terlambat mengembalikan buku.

Faktor penyebab keterlambatan pengembalian buku oleh mahasiswa UNP di Perpustakaan UNP yaitu karena mahasiswa lupa tanggal pengembalian buku, buku masih diperlukan karena kebutuhan kuliah dan tugas, mahasiswa yang pulang kampung, jadwal kuliah yang padat dan tugas yang banyak sehingga tidak sempat untuk ke Perpustakaan UNP. Penyebab keterlambatan pengembalian buku oleh mahasiswa UNP yang paling merugikan 
mahasiswa sendiri yaitu meminjamkan KTM (Kartu Tanda Mahasiswa) kepada teman untuk meminjam buku. Dampak penerapan sanksi administratif dalam meningkatkan kedisiplinan pemustaka belum membuat mahasiswa jera untuk tidak terlambat dalam mengembalikan buku dan mahasiswa masih saja mengulang keterlambatan dalam mengembalikan buku tersebut. Sanksi administratif berupa denda yang diterapkan oleh pihak Perpustakaan UNP belum membuat mahasiswa jera karena mahasiswa menganggap denda yang Rp. 1000 tidak terlalu besar sehingga mereka lebih memilih terlambat mengembalikan buku.

Cara mengatasi keterlambatan pengembalian buku yang dilakukan oleh pihak perpustakaan UNP yaitu dengan cara memberikan denda keterlambatan, memberikan peringatan kepada mahasiswa yang terlambat mengembalikan buku, memperbaiki sistem dengan cara menampilkan wajah mahasiswa pada saat meminjam buku sehingga tidak bisa lagi meminjam buku dengan memakai KTM mahasiswa lain, petugas memberitahukan tanggal jatuh tempo pengembalian buku kepada mahasiswa pada saat meminjam buku dan cara yang lainnya yaitu dengan memblokir portal mahasiswa yang sudah terlambat 6 bulan agar mahasiswa segera mengembalikan buku.

\section{Saran}

Adapun saran yang dapat diberikan penulis terkait dengan efektivitas penerapan sanksi administratif dalam meningkatkan kedisiplinanyang dapat dipertimbangkan oleh pihak Perpustakaan UNP dalam pembenahan yaitu agar mahasiswa UNP mengetahui tata tertib dan ketentuan sanksi keterlambatan pengembalian buku yang berlaku di Perpustakaan UNP sebaiknya diadakan kegiatan sosialisasi semaksimal mungkin dengan menggunakan berbagai macam media. Sehingga mahasiswa UNP mengetahui secara jelas mengenai tata tertib dan ketentuan sanksi keterlambatan pengembalian buku yang ada. Kegiatan sosialisasi ini dapat diadakan pada saat kegiatan PKKMB bagi mahasiswa baru, karena mahasiswa baru masih tidak tau mengenai tata tertib dan ketentuan sanksi yang berlaku. Kegiatan sosialisasi ini sangat penting bagi mahasiswa UNP karena dapat membantu mahasiswa UNP untuk memanfaatkan seluruh fasilitas Perpustakaan UNP secara bertanggung jawab. Website Perpustakaan UNP seharusnya lebih diberitahukan lagi kepada Mahasiswa UNP karena semua tata tertib sudah berada disana. Untuk meningkatkan kedisiplinan pemustaka khususnya mahasiswa UNP sebaiknya pihak Perpustakaan UNP lebih tegas dalam menjalankan sanksi keterlambatan pengembalian buku. Perpustakaan UNP bisa melakukannya dengan cara memberikan sanksi lain selain denda berupa uang seperti menerapkan sanksi skorsing peminjaman buku untuk beberapa hari dan juga memberikan 
sanksi sosial seperti pemajangan foto. Sanksi lain tersebut bisa diberikan bagi mahasiswa UNP yang sudah berulang kali terlambat mengembalikan buku dan jangka waktu keterlambatan yang tergolong lama.

Sebagai mahasiswa UNP sebaiknya memiliki rasa tanggung jawab dalam memanfaatkan fasilitas Perpustakaan UNP khususnya dalam hal peminjaman buku. Buku yang terdapat di Perpustakaan UNP jumlahnya hanya sedikit maka dari itu, seluruh mahasiswa UNP memakainya secara bergilir. Jika sudah waktunya untuk mengembalikan buku yang dipinjam harap dikembalikan tepat waktu sesuai dengan jatuh tempo tanggal pengembalian buku. Ataupun mahasiswa UNP bisa segera mengembalikan buku Perpustakaan UNP jika telah selesai memakainya serta memfotocopy halaman yang dibutuhkan. Hal-hal tersebut merupakan salah satu cara agar mahasiswa UNP bisa lebih disiplin dalam mengembalikan buku. Agar jumlah keterlambatan pengembalian buku dapat diminimalisasi sebaiknya tata tertib di Perpustakaan UNP menjelaskan agar mahasiswa UNP tidak meminjamkan KTM mereka kepada temannya. Karena hal ini dapat menyebabkan teman yang dipinjamkan KTM tersebut lupa jika telah meminjam buku atas nama KTM temannya.

\section{DAFTAR PUSTAKA}

Anggraini, Jum. 2012. Hukum Administrasi Negara. Yogyakarta: Graha Ilmu.

Hasibuan, Malayu. 2005. Manajemen Sumber Daya Manusia, edisi revisi cetakan ketujuh.Jakarta: Bumi Aksara.

Hidayat, Puji Dwi Utami. 2014. Analisis Faktor-Faktor Yang MempengaruhiKeterlambatan Pengembalian Koleksi Pada Layanan Sirkulasi Perpustakaan SMAN 5 Magelang. Jurnal Ilmu Perpustakaan Undip.

Maryatun. 2016. Evaluasi Peraturan Pelayanan Perpustakaandi Perpustakaan Fakultas Ekonomika dan Bisnis UGM. Jurnal Ilmu Perpustakaan dan Informasi UGM.

Pratama, Ratno. 2014. Persepsi Pemustaka Terhadap Kinerja PelayananPengguna Perpustakaan Politeknik Kesehatan Kendari. Jurnal Ilmu KomunikasiUniversitas Halu Oleo Kendari.

Rahayu, Lisda. 2014. Materi Pokok Layanan Perpustakaan. Jakarta: Universitas Terbuka.

Rahayuningsih, F.2007. Pengelolaan Perpustakaan. Yogyakarta: Graha Ilmu.

Sinungan, Muchdarsyah. 2008. Produktivitas Apa dan Bagaimana. Jakarta: Bumi Aksara.

Supriyadi. 2015. Penegakan Hukum DisiplinDalam Pengelolaan Perpustakaan. Jurnal Perpustakaan STAIN Kudus

Suriptianti, Dyah ayu. 2016. Analisis Sanksi Denda Terhadap Kedisiplinan Pengembalian Buku Di Perpustakaan Fakultas Ilmu Budaya Universitas Diponegoro. Jurnal Ilmu Perpustakaan Undip

Sutarno, NS. 2006. ManajemenPerpustakaan (Suatu Pendekatan Praktis). Jakarta: CV Sagung Seto. 
Suwarno, Wiji. 2010. Dasar-Dasar Ilmu Perpustakaan. Yogyakarta: Ar-Ruzz Media.

Wismanawati, Riski Tri. 2013. Efektivitas Sanksi Administratif Keterlambatan Pengembalian Bahan Pustaka Terhadap Kedisiplinan Pemustaka Di Kantor Perpustakaan Dan Arsip Daerah Kabupaten Banyumas. Jurnal Ilmu Perpustakaan Volume 2, Nomor 2. 